\title{
触 New Disease Reports \\ Natural occurrence of Ornithogalum mosaic virus newly reported on gladiolus in India
}

\author{
Charanjeet Kaur ${ }^{1}$, S.K. Raj ${ }^{1}$, S.K. Snehi ${ }^{1}$, A.K. Goel ${ }^{2}$ and R.K. Roy ${ }^{2}$ \\ ${ }^{1}$ Molecular Plant Virology, CSIR- National Botanical research Institute, Rana Pratap Marg, Lucknow-226001, Uttar Pradesh, \\ India; ${ }^{2}$ Botanic Garden, CSIR-National Botanical Research Institute, Rana Pratap Marg, Lucknow-226001, Uttar Pradesh, \\ India
}

*E-mail: skraj2@rediffmail.com

Received: 15 Jun 2011. Published: 19 Jul 2011. Keywords: RT-PCR, sequence analysis

Gladiolus is an important ornamental plant, grown for the floriculture industry in India. More than 110 cultivars are being maintained at the National Botanical Research Institute (NBRI), Lucknow. However, the quality and quantity of gladiolus flowers have been greatly reduced in the last two to three years due to virus infections of commercial importance. During December 2010 symptoms of mosaic, chlorotic spots on leaves and floral deformations were observed in 27 gladiolus plants growing at gardens of NBRI, Lucknow, India. Cucumber mosaic virus (CMV) and potyvirus infections have been recorded on gladiolus (Katoch et al., 2003); therefore the infection of these viruses was suspected. Plants with appropriate symptoms were tested for the presence of CMV and potyviruses by Western blot immunoassays. Three out of five samples were found positive with the antiserum for a potyvirus isolated from Narcisus sp. (Aminuddin $e$ al., 1999) but none reacted positively to CMV antiserum (PVAS 242a, ATCC, USA).

To confirm the identity of these viruses, RT-PCR was performed using CMV and potyvirus specific primers, and the total RNA of symptombearing and symptomless leaf samples of gladiolus isolated using the RaFlex Total RNA isolation kit (GeNei, Bangalore, India). Several attempts failed to amplify any RT-PCR amplicon using the coat protein gene specific primers of CMV(AM180922/AM180923) (Srivastava, 2003). RTPCR using a pair of degenerate oligonucleotide primers (Pot 1 and Pot 2) designed for Potyviridae (Gibbs \& Mackenzie, 1997) resulted in amplicons of expected size $(\sim 1.5 \mathrm{Kbp})$ from leaf samples of symptom-bearing gladiolus (3/5) but not from the healthy ones (Fig. 1). The amplicons obtained from three symptom-bearing samples were bi-directionally sequenced and the resulting consensus sequence was deposited in GenBank (Accession No. JF682235). BLASTn analysis (JF682235) revealed the highest sequence identity (87-88\%) with the polyprotein gene sequence of the Ornithogalum mosaic virus (OrMV) isolates including those from Iris tingitana (AY994107, AF203528, FJ618533); Narcissus spp. (AJ493580); Vanilla fragrans (AY845013, AY845014) and Ornithogalum thyrsoides (AF080587) and a 78\% sequence identity with that of the OrMV gladiolus virus isolate GLA-11 from the Netherlands (FJ573184).

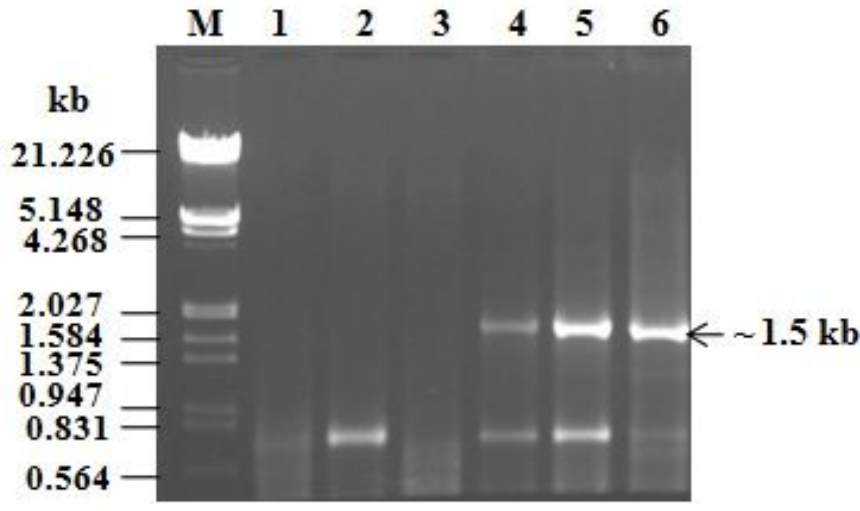

Phylogenetic analysis was performed using MEGA 4.0 tool (Tamura et al., 2007). This revealed the closest relationship of the virus isolate (JF682235) with isolates of OrMV from Narsicuss . (AJ493580), I. tingitana (AY994107, FJ618533, AF203528) and Vanilla . (AY845013, AY845014) (Fig. 2), which suggests the identification of an OrMV-related isolate in gladiolus in Lucknow, India. The existence of OrMV from India on $I$. tingitana has been previouslyreported (Chandel et al., 2006) but there is no record of natural occurrence of OrMV in gladiolus except from the Netherlands. The natural occurrence of OrMVon gladiolus is a new report from India that may have a phytosanitary impact on gladiolus export.

\section{References}

Aminuddin, Khan JA, Raj SK, 1999. Association of an unknown potyvirus isolate with severe mosaic of Narcissus tazetta L. Indian Journal of Experimental Biology, 37, 1034-1036.

Chandel V, Kulshrestha S, Hallan V, Zaidi AA, 2006. Natural infection of Ornithogalum mosaic virus on Iris from India. Plant Pathology 55, 284 http://dx.doi.org/10.1111/j.1365-3059.2005.01267.x

Gibbs A, Mackenzie A, 1997. A primer pair for amplifying part of the genome of all potyvirids by RT-PCR. Journal of Virological Methods, 63, 9-16. http://dx.doi.org/10.1016/S0166-0934(96)02103-9

Katoch M, Abdin MZ, Ram R, Zaidi AA, 2003. An overview of diagnostics for viruses infecting gladiolus. Crop Protection, 22, 153-156. http://dx.doi.org/10.1016/S0261-2194(02)00139-4

Srivastava A, 2003. Molecular characterization of a Cucumber mosaic virus (CMV) isolate infecting Amaranthus species and development of transgenic plants utilizing its coat protein gene for resistance against CMV. PhD Thesis, Department of Botany, University of Lucknow, Lucknow, India.

Tamura K, Dudley J, Nei M, Kumar S, 2007. MEGA4: Molecular Evolutionary Genetics Analysis (MEGA) software version 4.0. Molecular Biology and Evolution 24, 1596-1599.

Figure 1

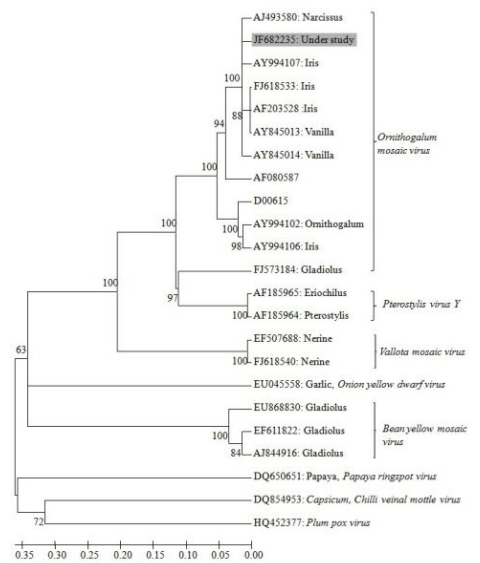

Figure 2

To cite this report: Kaur C, Raj SK, Snehi SK, Goel AK, Roy RK, 2011. Natural occurrence of Ornithogalum mosaic virus newly reported on gladiolus in India. New Disease Reports 24, 2. http://dx.doi.org/10.5197/j.2044-0588.2011.024.002

(c) 2011 The Authors

This report was published on-line at www.ndrs.org.uk where high quality versions of the figures can be found. 